\title{
The Relationship Between Corporate Governance Practices and Financial Performance: Evidence from Amman Stock Exchange
}

\author{
Hussein Ahmad Bataineh ${ }^{1}$, Sulaiman Salim Al Harthy ${ }^{2}$ \\ and Raqiya Ali Al Balushi ${ }^{3}$
}

\begin{abstract}
The objective of the study was to establish the relationship between corporate governance Index and financial performance and evidence from Amman stock exchange. To achieve this objective, this study applied descriptive research structure. In this case, the research focused on the 181 firms listed at the Amman Stock Exchange (Appendix I). The statistical techniques that was applied to analyze collected data included descriptive statistics. The information analyzed revealed that the model summary indicated that the $\mathrm{R}^{2}$ to be 0.243 . This meant that $24.3 \%$ of the variation in performance (ROA) was due to the predictor variable captured in the study. This also implied that $75.7 \%$ of the variation in ROA was attributed to the measurements of error and other factors that could have had an effect on the ROA but were not captured in the study. The estimated model showed that ROA when other factors are held constant was 1.610. The outcomes also revealed that governance score had a beta coefficient of 0.573 indicating that for every unit increase in governance score on the ROA went up by 0.573 . This relationship is significance since P-value of $0.025<0.05$. Therefore, the model qualified as a good predictor.
\end{abstract}

Keywords: Corporate Governance, Financial Performance, Amman stock Exchange.

\footnotetext{
${ }^{1}$ Research Scholar, Finance Department, Jordan University, Amman, Jordan.

2 Senior Islamic Banking Analyst, Central Bank of Oman, Oman.

${ }^{3}$ Internal Auditor, Bank Muscat, Oman.
}

Article Info: Received: January 22, 2021. Revised: February 17, 2021.

Published online: March 4, 2021. 


\section{Introduction}

\subsection{Background Information}

Corporate governance has become a significant concern for policymakers, academics, and corporate directors around the globe. The growing focus on corporate governance has been driven by the need to improve performance of organizations (Abdallah \& Ismail, 2017). It is expected to improve financial performance of organizations since it helps in directing and managing activities of the organization with an ultimate goal of maximizing shareholders with wealth while taking into account other stakeholders interest. Therefore, corporate governance enhances efficient and effective management which improves the firm's ability to generate revenues, meet its short-term obligations, make profits, and repay long-term loans as they fall due hence financial performance (Almajali, Alamro \& Al-Soub, 2012).

Corporate governance refers to the structures and processes in a company, including the relationship between the shareholders, management, and board of directors (Alabdullah, Yahya \& Ramayah, 2014). Different events made corporate governance a vital issue, such as the financial crisis in Brazil, Asia, and Russia in 1998, followed by the scandals in Europe and the United States. These instances, made people recognize the potential consequences of weakened corporate governance. For corporate governance to be successful, it should promote accountability, be fair, transparent, good leadership, and promote assurance and good stakeholder management (Yilmaz, 2018). Corporate governance measures include Gov-Score, a composite measure comprising of eight corporate governance categories (Audit, director education, executive and director compensation, charter/by laws, ownership, board of directors and progressive practices) (Brown \& Caylor, 2006). The other measure of corporate governance is corporate governance index, it is based on four factors of a firm's governance structure, that is,

Size of the board of director (SBD), Independence of the board of directors (IBD), CEO Duality (CEOD), number of committees formed in the board of directors (COMM) (Chen, Kao, Tsao \& Wu, 2007).

Financial performance is a measure of how well a firm can use its assets to generate revenue. Financial performance is an important part of cognitive science, whereby financial reports and analyses are needed to know the performance of the company and predict its future. Its need started after repression and the huge collapse of many companies in the late 20th century.

Financial analysis has been used in decision making. It interprets the results of the financial statement hence helpful in conducting the business operations and determining the ability of the company to perform its functions (Al-Ramahi, Barakat, \& Shahwan, 2014). It shows the continuity of the firm by showing the strengths and weaknesses of the company. Financial analysis entails financial ratio, profitability ratio, and return on assets rate. Among the measures used to estimate financial performance, we have, profitability ratios (return on assets, return on equity), solvency ratios (Debt to equity ratio) and Tobin Q (Fu, Singhal \& Parkash, 
2016).

Corporate governance, and financial performance are interrelated as they confirm the overall financial health of a company for a given period (Afkhami, 2014). Corporate governance is viewed as a framework for the company procedures to ensure that the procedures align with the objectives of the company (Zedan \& Abu Nassar, 2014). It is a determinant for success or failure for cooperation. The concept of financial analysis is used by the board of directors and the management to analyze the capacity of the business. It shows the efficiency of performance in its activities and function. It is helpful in forecasting and planning for the future, which is a vital tool in corporate governance as it promotes transparency and relates to investment decisions.

Amman stock exchange is a stock exchange institution in Jordan named after its capital city, Amman. It was established in 1999 march and authorized to trade securities. It is governed by seven directors, whereby the chief executive officer overlooks the daily responsibilities of the board. It comprises of sixty-eight members from brokerage firms (Al-Momani \& Almomni, 2018). It later became a state-owned company on 20th February 2017. It is based on four principles, which are fairness, liquidity, transparency, and efficiency. It provides a safe and strong environment for the securities while still protecting its investors. The company is known for providing firms with capital, encouraging active market, modern and transparent equipment for trading, and regulating the trade. It also provides timely and accurate information concerning the market to the public.

Amman Stock Exchange (ASE) is a vital economic activity that entails interactions and investments in huge volumes, which require a dividends movement and monitoring of the stock. Different variables determine their revenues, which are their corporate governance, and Financial

Performance. ASE has been able to maintain a positive performance due to good corporate governance despite the continuous political tension in some regions which have impacts on the economy. There is a strong application of corporate governance in the Amman stock exchange, which encompasses its shareholding companies. There is a relationship between the three variables in the Amman Stock Exchange, whereby transparency and disclosure is the most principle affecting the variables. The companies listed in the Amman stock exchange should continue implementing corporate governance while still applying the and corporate governance practices. Transparency and disclosure have an impact on the variables which reflect on the return on assets and profitability of the company (Moh'd, Al-Tamimi \& Obeidat, 2013).

\subsection{Statement of the Problem}

Corporate governance faces a lot of challenges resulting from investment and financial decisions. It is because the survival of a business relies on the financial and investment decisions. Therefore, corporate management can maximize its capacity or economic value by persistence earnings by the use of the company's 
assets. The relationship between corporate governance and financial performance has been conducted in previous studies. However, there are few studies on the relationship between corporate Governance Practices and Financial Performance. This study targets on filling the research gap. However, the majority of these studies focus on large and mature economies in European markets hence adding generalizability in understanding the relationships on the three. Global financial crisis differs in different countries, markets and companies based on economies (Abdallah \& Ismail, 2017). This has changed the understanding of the three variables bring sophistication. An open economy such as Jordan is a financial hub which has different experiences in corporate Governance Practices, and Financial Performance compared to other small economies. The study seeks to understand the three variables using Evidence from Amman Stock Exchange.

Various studies that have been conducted on Corporate Governance Practices, and financial performance include: Ibrahim and Ibrahim (2014) sought to examine the effect of cost capital factor on financial performance of SMEs in Nigeria. Cui and $\mathrm{Hu}$ (2014) sought to determine the effect of corporate management practices, outward foreign direct investments of publicly listed firms in China. Rad (2014) did an investigation among companies in Singapore and New Zealand on how corporate governance practices, cost capital affects financial performance. Haider and Khan (2015) examined whether corporate management practices contributes to investment cost and earnings among the Islamic Banks in Pakistan. Abdalla and Ismail (2016) evaluated ownership structure effect on financial performance among listed firm in the gulf corporative council. Orazalin and Mahmood (2016) reviewed corporate governance among the firms in Russian stock exchange, and its effect on financial performance. Mauteus and Belhaj (2016) studied firms in the USA with regards to various corporate regulatory practices and firm performance. Pham and Zein (2017) studied effect of corporate governance mechanism and cost capital on financial performance of firms in Australia. Buallay and Hamdah (2017) conducted a study on listed firms in Saudi Arabia, on corporate governance practices effect on financial performance. In conclusion, the studies present a contextual gap, as this study seeks to focus on all firms listed on Amman stock exchange in Jordan. There is also the variance in time, of which it will cover 2010 to 2019. Hence, this study seeks to fill this gap by answering the following research question, what is the effect of Corporate Governance Practices, and Financial Performance using evidence from the Amman Stock Exchange.

\subsection{Objectives of the Study}

The objective of the study was to establish the relationship between corporate governance practices, and financial performance and evidence from Amman stock exchange. 


\section{Literature Review}

\subsection{Theoretical Review}

In this section, three theories were reviewed because of their relevance to the study topic. The following theories raised insights to the study topic. The theories include Agency theory, Contingency theory and Stakeholder theory.

\subsubsection{Agency Theory}

The Agency theory was propounded by Jensen and Meckling (1976) which illustrates the difference between ownership and control of the firm. It states the relationship between the principle and the agent for fulfillment of the company's goal. For this case, the principle is the shareholder and the agents are the firm's directors who are employed by the shareholders. Directors are involved in decision making at the firm and they are mandated to make those decisions by putting into consideration the shareholder's needs. The expected changes when the agents work for the purpose of fulfilling their own self-interest for personal gain, hence conflict arises between the shareholders and the directors (Shapiro, 2005).

Mitnick (2013) argues that the conflict between the principle and the agent arise due to the cost of ownership and control, the following conflict should be handled by a neutral body which focuses on increasing the investments of the firm hence financial growth. The following theory will enable firms to understand the relevance of shareholders and managers in ensuring investments hence financial performance. Arthur (2003) the agency theory is critiqued since it focuses the agent as someone who is after attainment of a short-term goal this is generally not indicative of agent and their intimate involvement with the ventures they have founded.

\subsubsection{Stakeholder Theory}

Stakeholders "e theory was propounded by Freeman (1984); it focuses on the importance of the managers in ensuring that they make decisions at the best interest of each stakeholder of the company. All stakeholders contribute positively to the company's need and every stakeholder"e existence should not take for granted. Therefore when making critical decisions of the company by the management, suppliers, business partners and employees needs should be taken into consideration for ensuring firm performance (Freeman \& Harrison, 2010).

According to Ackermann and Eden (2011) the stakeholders have recruited the management in for the purpose of maximizing the financial performance; this is because the management has idea and information on how to exploit the market for their own advantage. Through ensuring financial support of the management, the stakeholders expect their investments to increase after the management has used it appropriately. Management should work hand in hand with the stakeholders for ensuring firm performance. The theory is relevant to the study since it depicts the role of corporate governance in supporting the finances of the firm through diverse investments hence financial performance. The theory was criticized by Ambler and Wilson (1995) since it just generalizes financial performance which is directly 
influenced by management and fails to state how the stakeholders should identify areas to invest for increasing competitive advantage that is key for financial performance of the firm.

\subsubsection{Contingency Theory}

Contingency theory was propounded by Fedler (1964) whereby; it explains that the decisions made by the manager on how the firm should operate are directly related financial performance. Therefore, the internal operation of the firm should be geared to the external market in the realization of firm's financial performance. Different organizations have different accounting systems which are not related to one another; therefore it is the mandate of the company's managers in control of the accounting systems hence financial performance of the firm. Decisions on investments, employee performance and risk management practices are most put into focus by the managers in ensuring financial performance (Donaldson, 2001). According to Linton (2013) the internal organization structure should be enhanced and internal resources should be maximized through investment hence financial performance. The manager's role is to ensure that they make decisions which enable efficient and effective investment opportunities for the firm hence performance. The following theory illustrates the relevance of the decisions made by the management in ensuring that the investment contributes to financial performance. Freeman (2015) the theory faces limitation since it relates the financial performance to internal processes of the firm and fails to acknowledge the fact that market is also a consideration when it comes to financial performance.

\subsection{Empirical Review}

Orazalin and Mahmood (2016) corporate governance among the firms in Russia, is highly adopted since it is believed to have an effect on financial performance. Pre and post research was conducted since the researcher aimed at examining whether corporate governance results from financial performance. Russian stock exchange listed firms that were used, and data collected were statistically analyzed through a panel regression model. According to the findings, corporate practices encourage cost capital which intern increases the profitability of the firm through investments hence financial performance. This finding was realized after the financial crisis whereby the financial performance had improved. The government should use the study in the determination of reasons behind economic growth, this is because the banking institutions' financial performance has a direct improvement in economic development.

Alabede (2016) various listed firms of the stock exchange have been experiencing financial performances. For this reason, they are known to be adopting some practices which have contributed to financial performance, corporate administrative practices have been known to be the contributor of financial performance in the UK. One hundred listed firms were involved in the research. Through Pearson correlation, data was analyzed to certain if the variables are related. Findings stated 
that corporate management is directly related to financial performance, capital investment is improved by the corporate governance practices since they welcome investors and reduce the price on return capital, therefore, contributing to profit maximization. Through corporate governance practices, the management is able to realize performance by exploiting the reduction of capital cost hence increases profits. Recommendations are made on the ability of the firm to ensure its financial increase through the adoption of corporate management strategies.

Mauteus and Belhaj (2016) Firms in the USA have realized increased earnings through the adoption of various corporate regulatory practices. This study determined various corporate regulatory practices and their influence on earnings and the manner in which cost capital is related to the two. Capital is known to be the most important element when it comes to increasing the investment niche of the company. Board composition was identified as a practice of the board which enables financial performance through profit maximization. Corporate governance is responsible for the implementation of practices that led to financial performance. The findings indicated that through the corporate governance practices, appropriate investors were welcomed to contribute to offering the firm with capita. Through given negotiations, the firm ensures that there was a mutual agreement in the reduction of return on capital to the investors, this, therefore, increased their financial performance. In conclusion, corporate governance should ensure the investors provide external capital at a reduced return on capital rate hence financial performance.

Buallay and Hamdah (2017) in Saudi Arabia, noted that corporate governance practices have largely contributed to financial performance among most listed firms. Adoption of these practices should be enforced by the management for ensuring financial performance. A total of

171 firms were involved in the study whereby the secondary record was obtained from records between years 2012 to 2014. Tobin Q model was used for measuring the relationship between corporate management and increased earnings. The findings indicated that corporate governance which was $61.4 \%$, had no influence on finances by the firm, factors such as the size of the board of directors and the ownership of the firm have an effect on increased profits. In conclusion for experiencing financial performance, the firm should consider advancing the board size of directors and firm ownership.

Rad (2014) did an investigation among companies in Singapore and New Zealand on how corporate governance practices, cost capital leads to financial performance. Various studies have investigated how corporate management influences increased earnings of firms in New Zealand. The study was conducted for the determination of the earnings of listed firms in New Zealand and Singapore since there has been recorded evidence on how both corporative governance practices and cost capital affects profits achievements. Through multiple regression, the connection between corporate regulatory, cost capitals on financial performances was analyzed. The findings indicated that there is a negative impact on investment cost when corporate governance practices are implemented hence increased investments. The board 
whether large or small can assist the companies in coming up with the appropriate cost of capital hence financial performance. Therefore, the managers are responsible in making the right decision on improving the cost capital hence financial performance but not the board composition.

Abdalla and Ismail (2016) evaluated ownership structure and financial performance among listed firm which are in the gulf corporative council raised concern for the researcher since they wanted to determine the effect it has on both corporative governance practices and cost capital. The development of the stock market among the Gulf region is associated with an increase in the number of investors who offer high-cost capital in supporting the stock trade market. The involvement of investors in ownership structure influences the corporative governance practices since they add value to the firm's earnings hence influences the financial increase of the firm. Improvement of the relationship between the corporate governance and the shareholders that is the investors strengthens the financial performance. This is because they work in fulfillment of the firms goals hence enhancing financial performances. The recommendation is made on how corporate governance should work hand in hand with the investors and strengthen their relationship for the realization of financial performance.

Haider and Khan (2015) examined whether corporate management practices contributes to investment cost and hence influences earnings among the Islamic Banks in Pakistan. Various studies have been conducted globally on corporate governance on financial performance and how they are related but they have failed to incorporate how the corporate governance promotes cost capital hence contributing to financial performance. From the records gathered, corporate management aims at bringing in the investors who provide cater for the investments to be invested and hence maximization of firms profits, therefore, financial performance. Therefore, investors should be encouraged to invest in the firms through corporate governance practices hence financial performance.

Zeitun (2014) investigated how corporate regulatory practices, capital structure, and financial performance of listed firms in five Gulf Cooperative Council (Kuwait, Bangladesh, Qatar, Saudi Arabia, and Oman). Through investigating whether the capital structure and corporative governance influences performance of these firms, the researcher achieved its goal. A total of 203 companies were involved whereby data between the years 2000 to 2010 were analyzed. From the findings, it is evident that capital structure has effect indirect impact on earnings but corporate governance has a positive and significant result on financial performance. This is because corporate management is responsible for welcoming the potential investors in investing in the company's resources hence profit maximization. In conclusion, firms should embrace good corporate regulatory practices for the purpose of achieving financial performance.

Cui and $\mathrm{Hu}$ (2014) determined the effect of corporate management practices, outward foreign direct investments of publicly listed firms in China. The firm ownership is essential in controlling of all the activities in the firm. Corporate governance ensures that the CEO's role is properly conducted through vital decision 
making which ensures financial performances. Through the involvement of 224 listed firms in investment corporate governance and ownership identity had identified to have a direct impact on financial performance. According to the findings outward, foreign direct investments have been encouraged by the CEO and the corporate governance, hence the financial performance as a result of profit maximization. In conclusion, it is the responsibility of the corporate governance and the $\mathrm{CEO}$ to encourage both domestic investors and outward foreign investors ${ }^{\mathrm{ec}}$ hence achievement to earnings.

Zabir and Wah (2016) explored various corporate management practices and the impact they pose on company's earnings of firms in Malaysia. Through examination of 100 firms in Malaysia, corporate governance has been identified as a factor which has direct influence on financial performance, hence a research was conducted to prove the following statement. The study adopted secondary data methodology which was sources from the previous records of the firms. Corporate governance was determined in terms of board size and independence which was later measured through the ROA and ROE. For testing the hypothesis, descriptive and correlation analysis were adopted. From the findings it is evident that board size is partially related to return of assets and had zero relationship to ROE, also there is zero relationship between board independence and financial performance. The study recommends that more research should be conducted on understanding the unifying factors that strengthen the relationship between the research variables and also adoption of corporate management should be encouraged hence performance.

Goel (2018) conducted a research in India whereby it aimed at determining the financial performance through assessing whether cost capital and corporate governance are related. Various studies have focused on improvement of financial performance but has failed to assess the factors contributing to financial performance, this study has stipulated factors contributing to financial performance and how they are related in achievement of performance. Forty-nine listed firms were involved in the study whereby their annual records from the year 2007 to 2017 were used as sources of data. From the findings, it is evident that financial performance of the firms are achieved through cost capital and corporate governance this is because, Corporate governance practices encourage the involvement of investors in the company's finances, hence increase in capital which results to profit maximization hence financial performance. Therefore firms are encouraged to strengthen and effectively implement the corporate regulatory practices and capital cost reduction if they want to improve financial performance. Mansur and Tangl (2018) listed firms by Amman Stock Exchange have over the years contributed to financial performance, this resulted to the researcher to conduct a researcher to examine whether corporate governance leads to financial performance. Through asses of previous records of the listed firms, data was gathered through a secondary data collection technique whereby, the descriptive research design was adopted. Elements of corporate governance such as ownership structure were found to be directly related to corporate governance. Type of ownership is also essential in the realization of financial performance, whereby 
institution ownership I preferred over the family ownership to corporate governance. In conclusion, financial performance was achieved through corporate governance hence firms can use this study in coming up with solutions for financial performance. Nasar and Zedan (2014) the manner and strategy adopted by corporate governance enhance financial performance. Does corporate management contribute to earnings of listed firms in the Amman Stock Exchange? Through assessing the relationship between corporate management practices and financial performance, the researcher used measurements such as return on asset, return on equity, total asset turnover and inventory turnover ratios, all this are the capital cost that the firm possesses. Records from 2004 to 2009 were used as data collection sources whereby a total of 69 firms were involved. The findings indicated that corporate governance is directly related to return on asset, return on equity, inventory turnover ratios, and total asset turnover which is related to company's earnings. Therefore, for the realization of financial performance, firms should embrace corporate governance.

Alsufy (2013) did research the involved listed industrial companies at the Amman Stock Exchange. Total of 44 firms were selected randomly and used as research samples for solving the research problem. The findings indicated that corporate governance practices are directly related to financial performance. This is because it generates maximum profits on factors such as earnings per share, return on asset, dividend per share, size of the firm which is responsible for the increment of investments, and finally liquidity. Recommendations entailed frequent check-up on ways to improve corporate regulatory practices quality and encouraging the usage of those practices for the purpose of increasing company's earnings through profit maximization.

Saidat and Seaman (2014) conducted a study in Jordan which involved the Amman Stock Exchange, whereby non-family and family firms were the case study. Some of the corporate governance mechanisms were assessed in whether they are related to financial performance. They determined that, usage of appropriate corporate governance mechanism ensures financial performance through profit maximization. The following study used measures such as ROA and market-based measures such as Tobin Q to determine financial performance. 228 listed firms participated in the research, whereby their records between the years 2009 to 2015 were used. From the findings it is evident that board size has zero impact on earnings since ROA and Tobin Q measured zero relationship between the two variables. In non-families it was recorded that independent directors provide the firms with resources such as capital for increasing investments hence financial performance through profit maximization. In conclusion, family listed firms should also emulate what the nonfamily firms are doing to improve their financial performance.

Abdallah and Yahya (2014) corporate governance mechanisms are used by various companies in Jordan, this is for the purpose of realization of firm financial performance. The following study determines various corporation mechanisms that have an effect on capital cost and hence financial performance of firms. 109 companies were used as sample in Jordan was involved in the study whereby their financial records of the year 2011 were analyzed. Through the use of a cross- 
sectional study, the hypothesis was tested. From the findings, presence of CEO duality, board size and independent directors ${ }^{\text {ee }}$ financial performance was not achieved. The implementation of market share variables is directly related to earnings of the firm. Composition of the board will determine the type and cost of investments that the firms will be involved with hence profit maximization that improves financial performance. In conclusion, corporate governance should ensure that it has reliable investors who are responsible for ensuring that they invest in increasing their market share in the market hence financial performance through an increase in competitive advantage.

Alrjoub and Ahmad (2017) inventory management has been recognized as a factor that contributes to financial performance by numerous firms in Jordan. The study goal was to assess whether the cost capital directly affects the financial performance of companies in Jordan. 48 companies were involved in the study whereby, the annual records of the years 2010 to 2016 were used as data sources. The findings were analyzed by Pearson correlation, they indicted that, inventory management types have an effect on the earnings of the firms. Cost capital moderates inventory management, therefore, strengthening the firm's gained profits. When inventory types and cost capital interacts, they pose a negative influence on financial performance. Recommendation is placed on capital cost consideration when defining the type of inventory to be used, this is facilitated by the corporate governance practices hence ensuring financial performance.

Almajari and Almaro (2013) conducted research in Jordan on listed Amman Stock Exchange to determine the financial performance. The main objective was to investigate factors that are responsible for financial performance among Jordan firms. Study samples from the year 2002 to 2007 was used. Multiple regression and T-test were used as data analysis tools. From the results it was evident that, corporate management which entails board composition, size, management, and leverage together with the cost of capital that had a direct impact on the earnings of the firms. Therefore, the recommendation is placed on various ways of increasing company assets through increased investment and employment of good management in controlling with the corporate governance practices for financial performance.

Eneizan and Matar (2018) conducted research in Jordan to determining the factors that contributes to earnings of the firms. Researcher aimed at determining the factors that contribute to the profits of firms at the Amman stock exchange. A total of 23 industries actively participated in the research and were used as a sample for the study. Records of the firm from the year 2005 to 2015 were used to source data. The findings indicated that the liquidity, profitability, revenue are related positively to ROA, which are components of capital cost which have a direct impact on the firm's earnings. Through consideration of the firm size, the firm will fail to perform this is because they have ignored the ability of corporate management practices. Study is significant since it would assist the stakeholders, investors, and policymakers in the realization of financial performance. 


\subsection{Summary of Literature Review}

From the above studies, it is evident that corporate management practices have a positive influence on financial performance. Corporate management is responsible for the determination of financial performance as long as it puts into consideration the accumulation of capital and the reduction in the cost of the returned capital. Market share ensures that the cost of capital is considered and the corporate governance practices encourage investors to hence increase in capital. An increase in capital increases the company's investments hence ensures profit maximization thus increase in FP.

\subsection{Research Gap}

The study reviewed global and regional literature on corporate governance and FP. The reviewed studies presented conceptual, contextual and methodological gap. Studies on cost of capital and FP were conducted by Ibrahim and Ibrahim (2014) and Alrjoub and Ahmad (2017) in Nigeria and Jordan respectively. Secondary data gathered covered the period 2008 to 2016.

Research on the effect of CG practices on the FP was conducted by Alsufy (2013), Saidat and Seaman (2014), Abdallah and Yahya (2014), Orazalin and Mahmood (2016), Alabede (2016), Mauteus and Belhaj (2016), Buallay and Hamdah (2017). The researches were carried out in various contexts such as Russian stock exchange, UK, USA, Saudi Arabia and Amman Stock Exchange in Jordan. The studies relied on secondary data that ranged between 2012 to 2015.

Investigation on CG practices, cost capital and FP was conducted by Rad (2014), Haider and Khan (2015), Pham and Zein (2017), Ghosh (2017) and Goel (2018). The studies were carried out in New Zealand, Singapore, Islamic Banks in Pakistan, Australia, North Africa and India. The study period covered 2003 to 2015.

Zeitun (2014) investigated on the link between the CG practices, capital structure and FP of listed firms in five Gulf Cooperative Council (Kuwait, Bangladesh, Qatar, Saudi Arabia and Oman). A total of 203 companies were involved whereby data of between the years 2000 to 2010 was analyzed. Cui and $\mathrm{Hu}$ (2014) determined the effect of the CG practices, outward foreign direct investments of publicly listed firms in China. Abdalla and Ismail (2016) evaluated the relationship between CG practices, the ownership structure and FP among listed firm which are in the gulf corporative council.

In conclusion, the studies presents a contextual gap, as this study seeks to focus on all firms listed on Amman stock exchange in Jordan. There is also the variance in time, of which it will cover 2010 to 2019.

\subsection{Conceptual Framework}

The diagrammatic representation below shows the link between the predictor variable, mediating variable and dependent variable. The predictor variable is represented by the CG index, mediating variable will be cost of equity and cost of debt while dependent variable is represented by Tobin $Q$ and Return on Assets. 
Independent Variable

Independent Variable

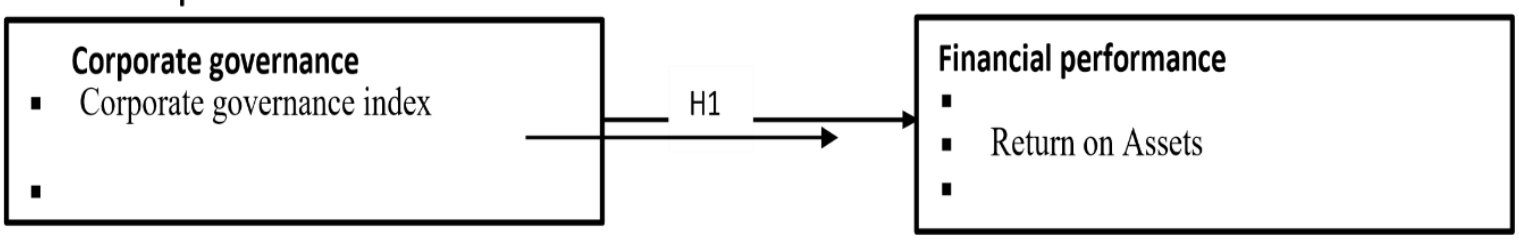

Figure 1: Conceptual Framework (Research 2020)

\section{Research Methodology}

\subsection{Introduction}

This section presents the approach that was used to carry out the study. It covered the following sub-topics: research design, population of the study, data collection, analysis and ethical consideration.

\subsection{Research Design}

A research design as per Creswel (2003) is a technique that was followed by researchers when conducting research. The process enables the researcher to make prior plans to enable them solve the identified research problem. Research issues are utilized to give deduction to the structure of an investigation's research issue, its system, design or arrangement of the examination's relationships with different variables of the research. The study design helps in the planning of an examination and in the securing of empirical evidence on these association.

This study applied descriptive research structure. A descriptive research alludes to a structure that includes a careful examination and survey of a subject's response with the point of understanding the depth of the study (Kothari, 2004). This process involved collection, analysis and presentation of analyzed information.

\subsection{Population of the Study}

Population of study as defined by Lewis and Thornhill (2009) is a collection of objects, numbers, or individuals who/which possess a common specific identity which is related to the study. In this case, the research focused on the 181 firms listed at the Amman Stock Exchange (Appendix I).

\subsection{Data Collection}

Data collection is the systematic approach of gathering of evidence, data and facts from an identified population for purpose of answering a stated research question (Morgan \& Harmon, 2001). The data includes the facts that are presented to researchers from an environment of study which mainly include the secondary data. The study utilized secondary data (quantitative) sourced from Amman Stock Exchange websites. 
Data relating to the CG was represented by CG index, and FP was represented by ROA. The data to be collected covered a period of 10 years, which is January 2010 - December 2019. The information was collected through a data collection sheet (Appendix II).

Table 1: Operationalization of Variables

\begin{tabular}{|c|c|c|}
\hline Variable & Measurement & Type of data \\
\hline Corporate governance & CG Index & Secondary \\
\hline FP & Return on assets & Secondary \\
\hline
\end{tabular}

\subsection{Data analysis}

Taylor and Cihon (2004) noted that analysis of data is the systematic process of applying logic techniques to describe, condense and evaluate large quantity of data collected. Data was edited, coded and entered in Statistical Packages of Social Sciences (SPSS) before analysis. The statistical techniques that was applied used to analyze collected data included descriptive statistics whereby the collected data was fed in the system of SPSS and later generate the outcomes descriptively in terms of mean scores, and standard deviation. Information analyzed through inferential statistics applied regression analysis.

To establish the extent to which the independent variable: CG index influence FP of firms listed on Amman Stock Exchange, multiple regression analysis was applied. The model is shown as below:

$\mathrm{Y}=\mathrm{a}+\beta_{1} \mathrm{X}_{1}+\beta_{2} \mathrm{X}_{2}+\beta_{3} \mathrm{X} 3+\varepsilon$ Where:

$Y=$ Financial-performance measured by return on Assets

$\mathrm{X} \mathbf{1}=\mathrm{CG}$ index (Appendix II) $\mathrm{a}=$ constant $\varepsilon=$ Error term $\beta 1, \beta 2$ and $\beta 3$ regression coefficient for predictor variables.

\section{Data Analysis, Results and Discussion}

\subsection{Descriptive Analysis}

This section presents the descriptive analysis output of this study of 181 firms listed on Amman Stock Exchange. Among the descriptive tested are mean, median and standard deviation. From the analysis of the descriptive statistics are presented in table 4.1 descriptive statistics. 
Table 2: Descriptive statistics

\begin{tabular}{|l|c|c|c|}
\hline & Mean & Median & Std. Dev. \\
\hline ROA & 2.243 & 1.865 & 1.370 \\
\hline Governance score & 52.73 & 51 & 8.560 \\
\hline Committees & 2.729 & 3 & 0.971 \\
\hline Independent directors & 49.063 & 45.34 & 17.64 \\
\hline CEO duality & 0.120 & 0 & 0.368 \\
\hline Board size & 11.723 & 10 & 0.379 \\
\hline
\end{tabular}

The finding clearly show that return on assets has a mean of 2.24 with a standard deviation of 1.370 , governance score had a weighted mean of 52.73 with a standard deviation of 8.560, number of committees had a mean score of 2.7 with a standard deviation of 0.971 , independent directors had a weighted mean of 49.06 with a standard deviation of 17.64, CEO duality scored a mean of 0.12 with a standard deviation of 0.368 while board size scored a mean of 11.72 with a standard deviation of 0.379 .

\subsection{Correlation Analysis}

Correlation analysis was used to establish if the nature of association between two variables which lies between (-) strong negative correlation and (+) perfect positive correlation.

Table 3: Correlation analysis

\begin{tabular}{|c|c|c|c|c|c|c|c|}
\hline & ROA & $\begin{array}{c}\text { Governance } \\
\text { score }\end{array}$ & Committees & $\begin{array}{c}\text { Independent } \\
\text { directors }\end{array}$ & $\begin{array}{c}\text { CEO } \\
\text { duality }\end{array}$ & $\begin{array}{c}\text { Board } \\
\text { Size }\end{array}$ \\
\hline ROA & 1 & & & & & \\
\hline Governance Score & 0.243 & 1 & & & & \\
\hline No. & of & & & & & & \\
\hline $\begin{array}{c}\text { Committees } \\
\text { Independent } \\
\text { Directors }\end{array}$ & & 0.034 & 0.327 & 1 & & & \\
\hline CEO Duality & & -0.039 & 0.226 & 0.263 & 1 & & \\
\hline Board size & & 0.047 & 0.418 & 0.146 & 0.172 & -0.021 & 1 \\
\hline
\end{tabular}

From the correlation analysis output, it can be noted that there exists a weak positive relationship $(\mathrm{R}=0.243)$ between return on assets and governance score. There exists a positive relationship between No. of committees and ROA at $(r=0.034)$; and 
governance score at 0.327 . Independent directors had a weak positive association with the following factors: ROA $(\mathrm{R}=0.039)$, Governance score $(\mathrm{R}=0.226)$, committees $(\mathrm{r}=0.263)$. CEO Duality had weak negative association with $\mathrm{ROA}(\mathrm{R}=-$ $0.001)$, Governance score ( $\mathrm{R}=-0.062)$, and a positive association with committees $(\mathrm{r}=0.021)$ and Board independence $(\mathrm{r}=0.107)$. Board size had a weak direct relationship with ROA $(\mathrm{R}=0.047)$, Governance score $(\mathrm{R}=0.418)$, Committees $(\mathrm{R}=0.146)$ and independent directors $(\mathrm{R}=0.172)$, while board size had a weak negative association with $(\mathrm{r}=-0.021)$.

\subsection{Regression Analysis}

In this study, a simple regression analysis was conducted to test the nature and significance of the relationship between the dependent and independent variable. The results were presented in the tables below.

Table 4: Model Summary

\begin{tabular}{|c|c|c|c|}
\hline Model & R & R Square & Adjusted R Square \\
\cline { 2 - 4 } & 0.243 & 0.0590 & 0.3625 \\
\hline
\end{tabular}

The model summary indicated that the $\mathrm{R}^{2}$ to be 0.243 . This meant that $24.3 \%$ of the variation in performance (ROA) was due to the predictor variable captured in the study. This also implied that $75.7 \%$ of the variation in ROA was attributed to the measurements of error and other factors that could have had an effect on the ROA but were not captured in the study.

Table 5: ANOVA

\begin{tabular}{|l|c|c|c|c|c|}
\hline Model & $\begin{array}{c}\text { Sum } \\
\text { Squares }\end{array}$ & $\begin{array}{c}\text { of } \\
\text { Df }\end{array}$ & Mean Square & F & Sig. \\
\hline Regression & 2.135 & 1 & 2.135 & 3.378 & 0.025 \\
\hline Residual & 113.128 & 179 & 0.632 & & \\
\hline Total & 115.263 & 180 & & & \\
\hline
\end{tabular}

The regression model was fit to predict the dependent variable. This is because of the significance value of $0.025<0.05$. Thus, the model with Governance score was therefore, fit predictor of ROA. 
Table 6: Coefficients

\begin{tabular}{|l|c|r|r|r|l|}
\hline \multirow{2}{*}{ Model } & \multicolumn{2}{|c|}{ Unstandardized Coefficients } & \multicolumn{2}{|c|}{ Standardized t Coefficients } & Sig. \\
\cline { 2 - 6 } & $\mathrm{B}$ & $\underline{\text { Std. Error }}$ & \multicolumn{2}{|c|}{ Beta } & \\
\hline (Constant) 1 & 1.610 & 0.392 & \multicolumn{2}{|c|}{4.111} & .000 \\
\hline Governance score & 0.573 & 0.102 & 0.688 & 5.616 & .025 \\
\hline
\end{tabular}

The findings in table 4.3 estimates the model for calculating the dependent variable given the value of the independent variable. The regression output in table above estimates the model for calculating the dependent variable given the value of the independent variable written as;

$\mathrm{Y}=1.610+0.573 \mathrm{X}$

The estimated model showed that ROA when other factors are held constant was 1.610. The outcomes also revealed that governance score had a beta coefficient of 0.573 indicating that for every unit increase in governance score on the ROA went up by 0.573 . This relationship is significance since P-value of $0.025<0.05$. Therefore, the model qualified as a good predictor.

\section{Conclusion}

From the findings the firms on the effect of Governance score on financial performance of firms Listed on Amman Stock Exchange. Thus the study concludes that governance score positively influence financial performance of firms listed on Amman Stock Exchange. A positive relationship between governance score and ROA will encourage listed firms to adopt corporate governance practices. 


\section{References}

[1] Abdallah, A. A. N., \& Ismail, A. K. (2017). Corporate governance practices, ownership structure, and corporate performance in the GCC countries. Journal of International Financial Markets, Institutions and Money, 46, 98-115.

[2] Ackermann, F., \& Eden, C. (2011). Strategic management of stakeholders: Theory and practice. Long range planning, 44(3), 179-196.

[3] Afkhami R. S. (2014). The relationship between corporate governance practices and cost of capital in large listed companies of New Zealand and Singapore (Doctoral dissertation, University of Waikato).

[4] Alabdullah, T. T. Y., Yahya, S., \& Ramayah, T. (2014). Corporate governance mechanisms and Jordanian companies' financial performance. Asian Social Science, 10(22), 247.

[5] Alabede, J. O. (2016). Effect of board diversity on corporate governance structure and operating performance: Evidence from the UK listed firms. Asian Journal of Accounting and Governance, 7, 67-80.

[6] Almajali, A. Y., Alamro, S. A., \& Al-Soub, Y. Z. (2012). Factors affecting the financial performance of Jordanian insurance companies listed at Amman Stock Exchange. Journal of Management research, 4(2), 266.

[7] Al-Momani, A., \& Almomni, T. (2018). The impact efficiency of using assets to enhance earnings quality in the jordanian industrial companies listed in the amman stock exchange: An empirical study. International Journal Of Business and Management, 2(2), 40-46.

[8] Al-Ramahi, N., Barakat, A., \& Shahwan, Y. (2014). The impact of corporate governance principles application on the financial performance of public shareholding companies listed in the Amman stock exchange. European journal of accounting auditing and finance research, 2(6), 100-117.

[9] Alrjoub, A. M. S., \& Ahmad, M. A. (2017). Inventory management, cost of capital and firm performance: evidence from manufacturing firms in Jordan. Investment management and financial innovations, (14,№ 3), 4-14.

[10] Alzurqan, S. T., \& Al_Sufy, F. J. (2011). The effect of corporate governance on the performance of Jordanian industrial companies: An empirical study on Amman Stock Exchange. International Journal of Humanities and Social Science, 55-69.

[11] Ambler, T., \& Wilson, A. (1995). Problems of stakeholder theory. Business Ethics: A European Review, 4(1), 30-35.

[12] Brown, L. D., \& Caylor, M. L. (2006). Corporate governance and firm valuation. Journal of accounting and public policy, 25(4), 409-434.

[13] Buallay, A., Hamdan, A., \& Zureigat, Q. (2017). Corporate governance and firm performance: evidence from Saudi Arabia. Australasian Accounting, Business and Finance Journal, 11(1), 78-98.

[14] Busenitz, J \& Arthur, D (2003). The boundary and limitation od agency theory and stewardship theory in the venture/capitalist entrepreneur relationship. Entrepreneur: Theory and Practice28(2) 149-162 
[15] Chen, A., Kao, L., Tsao, M., \& Wu, C. (2007). Building a corporate governance index from the perspectives of ownership and leadership for firms in Taiwan. Corporate Governance: An International Review, 15(2), 251-261.

[16] Creswell, J. (2003). Research design: Qualitative, quantitative and mixed methods approaches (2nd ed.). Thousand Oaks, CA: SAGE Publications.

[17] Donaldson, L. (2001). The contingency theory of organizations. Sage.

[18] Donaldson, L., \& Davis, J. H. (1991). Stewardship theory or agency theory: CEO governance and shareholder returns. Australian Journal of management, 16(1), 49-64.

[19] Doval, E. (2018). The cost of capital and financial risk from investors ,perspective. Review of General Management, 27(1).

[20] Freeman, J. (2015). Contingency theory. Wiley Encyclopedia of Management, $1-1$.

[21] Freeman, R. E., Harrison, J. S., Wicks, A. C., Parmar, B. L., \& De Colle, S. (2010). Stakeholder theory: The state of the art. Cambridge University Press.

[22] Fu, L., Singhal, R., \& Parkash, M. (2016). Tobin's q ratio and firm performance. International Research Journal of Applied Finance, 7(4), 1-10.

[23] Ghosh, S. (2017). Corporate governance reforms and bank performance: evidence from the Middle East and North Africa. Corporate Governance: The International Journal of Business in Society.

[24] Goel, P. (2018). Implications of corporate governance on financial performance: an analytical review of governance and social reporting reforms in India. Asian Journal of Sustainability and Social Responsibility, 3(1), 4.

[25] Haider, N., Khan, N., \& Iqbal, N. (2015). Impact of corporate governance on firm financial performance in Islamic financial institution. International letters of social and humanistic sciences, 51, 106-110.

[26] $\mathrm{Hu}$, Helen Wei, and Lin Cui. "Outward foreign direct investment of publicly listed firms from China: A corporate governance perspective." International Business Review 23, no. 4 (2014): 750-760.

[27] Ibrahim, M., \& Ibrahim, A. (2015). The effect of SMEse cost of capital on their financial performance in Nigeria. Journal of finance and accounting, 3(1), 811.

[28] Kothari, C. R (2004). "Research Methodology - Methods \& Techniques" New Age Linton, G. (2014). Contingency theory in entrepreneurship research.

[29] Mansur, H., \& Tangl, A. (2018). The effect of corporate governance on the financial performance of listed companies in Amman stock exchange (Jordan). Journal of Advanced Management Science Vol, 6(2), 97-102.

[30] Matar, A., \& Eneizan, B. M. (2018). Determinants of financial performance in the industrial firms: Evidence from Jordan. Asian Journal of Agricultural Extension, Economics \& Sociology, 1-10.

[31] Mateus, C., \& Belhaj, S. (2016). Corporate governance impact on bank performance: Evidence from Europe. Corporate Ownership and Control, 13(4), 583-597. 
[32] Mitnick, B. (2017). Origin of the Theory of Agency: An Account By One of the Theory's Originators.SSRN,96-116.accessedfrom https://papers.ssrn.com/sol3/papers.cfm?abstract_id=1020378

[33] Moh'd Al-Tamimi, K. A., \& Obeidat, S. F. (2013). Impact of cost of capital, financial leverage, and the growth rate of dividends on the rate of return on investment an empirical study of Amman stock exchange. International Journal of Academic Research in Economics and Management Sciences, 2(4), 59.

[34] Orazalin, N., Mahmood, M., \& Lee, K. J. (2016). Corporate governance, financial crises and bank performance: lessons from top Russian banks. Corporate Governance: The International Journal of Business in Society.

[35] Polit, D. F., \& Beck, C. T. (2010). Generalization in quantitative and qualitative research: Myths and strategies. International journal of nursing studies, 47(11), 1451-1458

[36] Saidat, Z., Silva, M., \& Seaman, C. (2019). The relationship between corporate governance and financial performance. Journal of Family Business Management.

[37] Shapiro, S. P. (2005). "Agency theory." Annu. Rev. Sociol. 31: 263-284.

[38] Suchard, J. A., Pham, P. K., \& Zein, J. (2012). Corporate governance and the cost of capital: evidence from Australian firms. Journal of Applied Corporate Finance, 24(3), 84-93.

[39] Taylor, J. K., \& Cihon, C. (2004). Statistical techniques for data analysis. CRC Press.

[40] Yilmaz, I. (2018). Corporate governance and financial performance relationship: the case for Oman companies.

[41] Zabri, S. M., Ahmad, K., \& Wah, K. K. (2016). Corporate governance practices and firm performance: Evidence from top 100 public listed companies in Malaysia. Procedia Economics and Finance, 35, 287-296.

[42] Zedan, H. I., \& Abu Nassar, M. (2014). The Effect of Corporate Governance on Operating Performance of Jordanian Manufacturing Companies: Evidence from Amman Stock Exchange. Dirasat: Administrative Sciences, 161(1524), $1-40$.

[43] Zedan, H. I., \& Abu Nassar, M. (2014). The Effect of Corporate Governance on Operating Performance of Jordanian Manufacturing Companies: Evidence from Amman Stock Exchange. Dirasat: Administrative Sciences, 161(1524), $1-40$.

[44] Zeitun, R. (2014). Corporate governance, capital structure and corporate performance: evidence from GCC countries. Review of Middle East Economics and Finance Rev. Middle East Econ. Fin., 10(1), 75-96. 
The Relationship Between Corporate Governance Practices and Financial...

APPENDICES

APPENDIX I: LIST OF FIRMS LISTED IN AMMAN STOCK EXCHANGE

\begin{tabular}{|c|c|c|c|}
\hline \multicolumn{4}{|c|}{ AMMAN STOCK EXCHANGE } \\
\hline & Company's name & & Company's name \\
\hline 1 & JORDAN ISLAMIC BANK & 34 & NATIONAL PORTFOLIO SECURITIES \\
\hline 2 & JORDAN KUWAIT BANK & 35 & JORDANIAN EXPATRIATES INVESTMENT HOLDI \\
\hline 3 & JORDAN COMMERCIAL BANK & 36 & JORDAN INVESTMENT TRUST \\
\hline 4 & THE HOUSING BANK FOR TRADE \& FIN. & 37 & ALDAMAN FOR INVESTMENTS \\
\hline 5 & ARAB JORDAN INVESTMENT BANK & 38 & UNION INVESTMENT CORPORATION \\
\hline 6 & SAFWA ISLAMIC BANK & 39 & JORDAN LOAN GUARANTEE CORPORATION \\
\hline 7 & BANK AL ETIHAD & 40 & ARAB EAST INVESTMENT \\
\hline 8 & ARAB BANKING CORPORATION & 41 & AL-AMIN FOR INVESTMENT \\
\hline 9 & INVEST BANK & 42 & UNITED FINANCIAL INVESTMENTS \\
\hline 10 & CAPITAL BANK OF JORDAN & 43 & JORDAN MORTGAGE REFINANCE \\
\hline 11 & SOCIETE GENERALE DE BANQUE -JO & 44 & INTERNATIONAL BROKERAGE \& FINANCIAL MKTS \\
\hline 12 & CAIRO AMMAN BANK & 45 & AL-AMAL FINANCIAL INVESTMENTS CO. \\
\hline 13 & BANK OF JORDAN & 46 & AL SANABEL INT. FOR ISLAMIC INVEST. PLC. CO. \\
\hline 14 & JORDAN AHLI BANK & 47 & AL-BILAD SECURITIES AND INVESTMENT \\
\hline 15 & ARAB BANK & 48 & FIRST FINANCE \\
\hline 16 & MIDDLE EAST INSURANCE & 49 & JORDANIAN MANAGEMENT AND CONSULTING \\
\hline 17 & AL-NISR AL-ARABI INSURANCE & 50 & FUTURE ARAB INVESTMENT COMPANY \\
\hline 18 & JORDAN INSURANCE & 51 & BABELON INVESTMENTS CO. P.L.C \\
\hline 19 & ARABIA INSURANCE COMPANY - JORDA & 52 & INTERNATIONAL CARDS COMPANY \\
\hline 20 & DELTA INSURANCE & 53 & KAFA`A FOR FINANCIAL \& ECONOMICAL INVEST. \\
\hline 21 & JERUSALEM INSURANCE & 54 & TUHAMA FOR FINANCIAL INVESTMENTS \\
\hline 22 & THE UNITED INSURANCE & 55 & FIRST JORDAN INVESTMENT COMPANY PLC \\
\hline 23 & JORDAN FRENCH INSURANCE & 56 & DIMENSIONS:JORDAN AND EMIRATES COMMER \\
\hline 24 & AL-MANARA INSURANCE PLC.CO. & 57 & DARAT JORDAN HOLDINGS \\
\hline 25 & ARAB ORIENT INSURANCE COMPANY & 58 & SABAEK INVEST COMPANY P.L.C \\
\hline 26 & ARAB LIFE \& ACCIDENT INSURANCE & 59 & ALISRAA FOR ISLAMIC FINANCE AND INVEST. \\
\hline 27 & PHILADELPHIA INSURANCE & 60 & RUMM FINANCIAL BROKERAGE \\
\hline 28 & ARAB UNION INTERNATIONAL INSURAN & 61 & AKARY FOR INDUSTRIES AND REAL ESTATE INVES \\
\hline 29 & NATIONAL INSURANCE & 62 & Jordanian CO. For Developing \& Financial Invest \\
\hline 30 & JORDAN INTERNATIONAL INSURANCE & 63 & JORDANIAN MUTUAL FUNDS MANAGEMENT CO. \\
\hline 31 & EURO ARAB INSURANCE GROUP & 64 & AL-BILAD MEDICAL SERVICES \\
\hline 32 & THE ISLAMIC INSURANCE & 65 & THE CONSULTANT \& INVESTMENT GROUP \\
\hline 33 & $\begin{array}{l}\text { THE ARAB ASSURERS INSURANCE } \\
\text { CO. }\end{array}$ & 66 & IBN ALHAYTHAM HOSPITAL COMPANY \\
\hline
\end{tabular}




\begin{tabular}{|c|c|c|c|}
\hline 67 & ARAB JORDANIAN INSURANCE GROUP & 93 & INTERNATIONAL FOR MEDICAL INVESTMENT \\
\hline 68 & $\begin{array}{l}\text { THE MEDITERRANEAN \& GULF } \\
\text { INSURANCE COMPANY-JORDAN }\end{array}$ & 94 & AL-ZARQA EDUCATIONAL \& INVESTMENT \\
\hline 69 & FIRST INSURANCE & 95 & $\begin{array}{l}\text { THE ARAB INTERNATIONL FOR EDUCATION \& } \\
\text { INVESTMENT. }\end{array}$ \\
\hline 70 & $\begin{array}{l}\text { ALSHAMEKHA FOR REALESTATE AND } \\
\text { FINANCIAL INVESTMENTS }\end{array}$ & 96 & AL-ISRA FOR EDUCATION AND INVESTMENT "PLC" \\
\hline 71 & JORDAN DECAPOLIS PROPERTIES & 97 & PETRA EDUCATION COMPANY \\
\hline 72 & $\begin{array}{l}\text { AL-TAJAMOUAT FOR TOURISTIC } \\
\text { PROJECTS CO PLC }\end{array}$ & 98 & $\begin{array}{l}\text { PHILADELPHIA INTERNATIONAL } \\
\text { EDUCATIONAL INVESTMENT COMPANY }\end{array}$ \\
\hline 73 & $\begin{array}{l}\text { UNION LAND DEVELOPMENT } \\
\text { CORPORATION }\end{array}$ & 99 & JORDAN HOTELS \& TOURISM \\
\hline 74 & $\begin{array}{l}\text { AL-TAJAMOUAT FOR CATERING AND } \\
\text { HOUSING CO PLC }\end{array}$ & 100 & ARAB INTERNATIONAL HOTELS \\
\hline 75 & $\begin{array}{l}\text { SPECIALIZED INVESTMENT } \\
\text { COMPOUNDS }\end{array}$ & 101 & MEDITERRANEAN TOURISM INVESTMENT \\
\hline 76 & SPECIALIZED JORDANIAN INVESTMENT & 102 & ZARA INVESTEMENT HOLDING \\
\hline 77 & REAL ESTATE DEVELOPMENT & 103 & AL- SHARQ INVESTMENTS PROJECTS(HOLDING) \\
\hline 78 & $\begin{array}{l}\text { THE REAL ESTATE \& INVESTMENT } \\
\text { PORTFOLIO CO. }\end{array}$ & 104 & AL-DAWLIYAH FOR HOTELS \& MALLS \\
\hline 79 & $\begin{array}{l}\text { ARAB EAST FOR REAL ESTATE } \\
\text { INVESTMENTS CO } \\
\end{array}$ & 105 & JORDAN PROJECTS FOR TOURISM DEVELOPMENT \\
\hline 80 & $\begin{array}{l}\text { INT'L ARABIAN DEVELOPMENT AND } \\
\text { INVESTMENT TRADING CO. }\end{array}$ & 106 & AL-RAKAEZ INVESTMENT CO. \\
\hline 81 & $\begin{array}{l}\text { JORDANIAN REALESTATE } \\
\text { COMPANY FOR DEVELOPMENT }\end{array}$ & 107 & SURA DEVELOPMENT \& INVESTMENT PLC \\
\hline 82 & $\begin{array}{l}\text { AMAD INVESTMENT \& REAL ESTATE } \\
\text { DEVELOPMENT }\end{array}$ & 108 & JORDAN NATIONAL SHIPPING LINES \\
\hline 83 & IHDATHIAT CO-ORDINATES & 109 & SALAM INTERNATIONL TRANSPORT \& TRADING \\
\hline 84 & $\begin{array}{l}\text { EMMAR INVESTMENTS \& } \\
\text { REALESTATE DEVELOPMENT }\end{array}$ & 110 & JORDAN EXPRESS TOURIST TRANSPORT \\
\hline 85 & ARAB PHOENIX HOLDINGS & 111 & JORDAN INVESTMENT \& TRANSPORT CO. \\
\hline 86 & METHAQ REAL ESTATE INVESTMENT & 112 & TRANSPORT\& INVESTMENT BARTER COMPANY \\
\hline 87 & CONTEMPRO FOR HOUSING PROJECTS & 113 & ALIA- THE ROYAL JORDANIAN AIRLINES PLC. \\
\hline 88 & $\begin{array}{l}\text { NOOR CAPITAL MARKTS FOR } \\
\text { DIVERSIFIED INVESTMENTS }\end{array}$ & 114 & MASAFAT FOR SPECIALISED TRANSPORT \\
\hline 89 & $\begin{array}{l}\text { HIGH PERFORMANCE REAL ESTATE } \\
\text { INVESTMENTS }\end{array}$ & 115 & $\begin{array}{l}\text { COMPREHENSIVE MULTIPLE TRANSPORTATIONS } \\
\text { CO. }\end{array}$ \\
\hline 90 & $\begin{array}{l}\text { ARAB INVESTORS UNION CO. FOR REAL } \\
\text { ESTATES DEVELOPING }\end{array}$ & 116 & $\begin{array}{l}\text { RUM GROUP FOR TRANSPORTATION \& TOURISM } \\
\text { INVESTMENT }\end{array}$ \\
\hline 91 & $\begin{array}{l}\text { JORDAN INTERNATIONAL INVESTMENT } \\
\text { CO. }\end{array}$ & 117 & JORDAN TELECOM \\
\hline 92 & $\begin{array}{l}\text { DEERA INVESTMENT \& REAL ESTATE } \\
\text { DEVELOPMENT CO }\end{array}$ & 118 & $\begin{array}{l}\text { AL-FARIS NATIONAL COMPANY FOR INVESTMENT \& } \\
\text { EXPORT }\end{array}$ \\
\hline
\end{tabular}


The Relationship Between Corporate Governance Practices and Financial...

\begin{tabular}{|c|c|c|c|}
\hline 119 & $\begin{array}{l}\text { AL-TAHDITH FOR REAL ESTATE } \\
\text { INVESTMENTS COMPANY }\end{array}$ & 144 & JORDAN PRESS FOUNDATION/AL-RA'I \\
\hline 120 & $\begin{array}{l}\text { THE PROFESSIONAL COMPANY } \\
\text { FOR REAL ESTATE INVESTMENT AND } \\
\text { HOUSING }\end{array}$ & 145 & JORDAN ELECTRIC POWER \\
\hline 121 & $\begin{array}{l}\text { SHIRA REAL ESTATE } \\
\text { DEVELOPMENT \& INVESTMENTS }\end{array}$ & 146 & IRBID DISTRICT ELECTRICITY \\
\hline 122 & AMWAJ PROPERTIES & 147 & AFAQ FOR ENERGY CO. P.L.C \\
\hline 123 & \begin{tabular}{|l|} 
JORDAN MASAKEN FOR LAND \& \\
INDUSTRIAL DEVELOPMENT PROJECTS
\end{tabular} & 148 & NATIONAL PETROULEUM \\
\hline 124 & $\begin{array}{l}\text { AMOUN INTERNATIONAL FOR } \\
\text { INVESTMENTS }\end{array}$ & 149 & JORDAN PETROLEUM REFINERY \\
\hline 125 & $\begin{array}{l}\text { ALENTKAEYA FOR } \\
\text { INVESTMENT\&REALESTATE } \\
\text { DEVELOPMENT COMPANY PLC }\end{array}$ & 150 & JORDANIAN DUTY FREE SHOPS \\
\hline 126 & $\begin{array}{l}\text { ARAB COMPANY FOR INVESTMENT } \\
\text { PROJECTS }\end{array}$ & 151 & JORDAN INTERNATIONAL TRADING CENTER \\
\hline 127 & $\begin{array}{l}\text { COMPREHENSIVE LAND } \\
\text { DEVELOPMENT AND INVESTMENT } \\
\end{array}$ & 152 & JORDAN POULTRY PROCESSING \& MARKETING \\
\hline 128 & $\begin{array}{l}\text { AD-DULAYL INDUSTRIAL PARK \& REAL } \\
\text { ESTATE COMPANY P.L.C }\end{array}$ & 153 & JORDAN DAIRY \\
\hline 129 & JORDAN TRADE FAC & 154 & GENERAL INVESTMENT \\
\hline 130 & SPECIALIZED TRADING \& INVESTMENT & 155 & UNIVERSAL MODERN INDUSTRIES \\
\hline 131 & $\begin{array}{l}\text { BINDAR TRADING \& INVESTMENT CO } \\
\text { P.L.C }\end{array}$ & 156 & NATIONAL POULTRY \\
\hline 132 & OFFTECHOLDING GROUP PLC & 157 & NUTRI DAR \\
\hline 133 & SOUTH ELECTRONICS & 158 & JORDAN VEGETABLE OIL INDUSTRIES \\
\hline 134 & $\begin{array}{l}\text { NOPAR FOR TRADING AND } \\
\text { INVESTMENT } \\
\end{array}$ & 159 & SINIORA FOOD INDUSTRIES PLC \\
\hline 135 & $\begin{array}{l}\text { COMPREHENSIVE LEASING COMPANY } \\
\text { PLC }\end{array}$ & 160 & AL-EQBAL INVESTMENT COMPANY LTD \\
\hline 136 & INJAZ FOR DEVELOPMENT \& PROJECTS & 161 & UNION TOBACCO \& CIGARETTE INDUSTRIES \\
\hline 137 & $\begin{array}{l}\text { DAR AL DAWA DEVELOPMENT \& } \\
\text { INVESTMENT } \\
\end{array}$ & 162 & ARAB ALUMINIUM INDUSTRY /ARAL \\
\hline 138 & $\begin{array}{l}\text { THE JORDANIAN PHARMACEUTICAL } \\
\text { MANUFACTURING } \\
\end{array}$ & 163 & NATIONAL STEEL INDUSTRY \\
\hline 139 & $\begin{array}{l}\text { HAYAT PHARMACEUTICAL INDUSTRIES } \\
\text { CO. }\end{array}$ & 164 & JORDAN PHOSPHATE MINES \\
\hline 140 & PHILADELPHIA PHARMACEEUTICALS & 165 & THE JORDAN CEMENT FACTORIES \\
\hline 141 & $\begin{array}{l}\text { THE INDUSTRIAL COMMERCIAL \& } \\
\text { AGRICULTURAL }\end{array}$ & 166 & THE ARAB POTASH \\
\hline 142 & $\begin{array}{l}\text { PREMIER BUSINESS AND PROJECTS } \\
\text { CO.LTD }\end{array}$ & 167 & JORDAN STEEL \\
\hline 143 & JORDAN CHEMICAL INDUSTRIES & 168 & NATIONAL ALUMINIUM INDUSTRIAL \\
\hline
\end{tabular}




\begin{tabular}{|c|l|c|l|}
\hline 169 & NATIONAL CHLORINE INDUSTRIES & 179 & ASSAS FOR CONCRETE PRODUCTS CO. LTD \\
\hline 170 & JORDAN INDUSTRIAL RESOURCES & 180 & TRAVERTINE COMPANY LTD \\
\hline 171 & $\begin{array}{l}\text { THE ARAB PESTICIDES \& VETERINARY } \\
\text { DRUGS MFG. CO. }\end{array}$ & 181 & $\begin{array}{l}\text { UNITED IRON \& STEEL } \\
\text { MANUFACTURING CO. P.L.C }\end{array}$ \\
\hline 172 & $\begin{array}{l}\text { INTERMEDIATE PETROCHEMICALS } \\
\text { INDUSTRIES CO. LTD. }\end{array}$ & 182 & NORTHERN CEMENT CO. \\
\hline 173 & $\begin{array}{l}\text { AFAQ HOLDING FOR INVESTMENT \& } \\
\text { REAL ESTATE DEVELOPMENT CO. P.L.C }\end{array}$ & 183 & NATIONAL CABLE \& WIRE MANUFAC \\
\hline 174 & THE JORDAN PIPES MANUFACTURING & 184 & ARAB ELECTRICAL INDUSTRIES \\
\hline 175 & JORDAN WOOD INDUSTRIES / JWICO & 185 & UNITED CABLE INDUSTRIES \\
\hline 176 & $\begin{array}{l}\text { READY MIX CONCRTE \& CONSTRUCTION } \\
\text { SUPPLIES }\end{array}$ & 186 & CENTURY INVESTMENT GROUP \\
\hline 177 & $\begin{array}{l}\text { ARABIAN STEEL PIPES } \\
\text { MANUFACTURING }\end{array}$ & 187 & THE JORDAN WORSTED MILLS \\
\hline 178 & AL-QUDS READY MIX & 188 & EL-ZAY READY WEAR MANUFACTURIN \\
\hline
\end{tabular}


APPENDIX II: Corporate Governance Index

\begin{tabular}{|l|l|}
\hline Corporate governance index & $2010-2019$ \\
\hline Size of the board of director (SBD) & \\
\hline Independence of the board of directors (IBD) & \\
\hline CEO Duality (CEOD) & \\
\hline $\begin{array}{l}\text { Number of committees formed in the board of } \\
\text { directors (COMM) }\end{array}$ & \\
\hline
\end{tabular}

APPENDIX III: OPERATIONALIZATION OF VARIABLES

\begin{tabular}{|c|c|c|}
\hline Variables & Indicators & Measure \\
\hline \multicolumn{3}{|c|}{ CORPORATE GOVERNANCE (INDEPENDENT VARIABLE) } \\
\hline \multirow{4}{*}{ Corporate Governance Index } & $\begin{array}{l}\text { Size of the board of director } \\
\text { (SBD) }\end{array}$ & \\
\hline & $\begin{array}{l}\text { Independence of the board of } \\
\text { directors (IBD) }\end{array}$ & \\
\hline & CEO Duality (CEOD) & \\
\hline & $\begin{array}{l}\text { number of committees formed } \\
\text { in the board of directors } \\
\text { (COMM) }\end{array}$ & \\
\hline \multicolumn{3}{|c|}{ FINANCIAL PERFORMANCE (DEPENDENT VARIABLE) } \\
\hline Return on Assets (ROA) & $\begin{array}{c}\text { Ratio of operating income and } \\
\text { total assets }\end{array}$ & $\begin{array}{c}\mathrm{ROA}=\mathrm{Net} \\
\text { Income/Total } \\
\text { Assets }\end{array}$ \\
\hline
\end{tabular}

